\title{
Analysis of viral load, CD4+ and CD8+ T-cell from HIV-I infected patients enrolled in the AIDS programs from the city of Santos, Brazil
}

\author{
AC Zetehaku*1, AFP Lins-Filho1, JT Rabelato1, JC Tobara1, NC Nahon¹, \\ NT Santos ${ }^{1}$, RBR Matias ${ }^{1}$, RG Comparini ${ }^{1}$, RF Ambar ${ }^{1}$, LH Gagliani ${ }^{1}$, \\ S Komninakis ${ }^{1}$, RS Diaz ${ }^{2}$, AAC Golegã ${ }^{1}$, MM Caseiro $^{1}$ and DJ Sa-Filho ${ }^{1}$
}

Address: ${ }^{1}$ Centro Universitário Lusíada (UNILUS), Santos, Brazil and ${ }^{2}$ UNIFESP, Sao Paulo, Brazil

* Corresponding author

from Ninth International Congress on Drug Therapy in HIV Infection

Glasgow, UK. 9-13 November 2008

Published: 10 November 2008

Journal of the International AIDS Society 2008, I I (SuppI I):P209 doi:I0.II86/I758-2652-II-SI-P209

This abstract is available from: http://www.jiasociety.org/content/I I/SI/P209

(c) 2008 Zetehaku et al; licensee BioMed Central Ltd.

\section{Purpose of the study}

In 1996 Santos was the first city in Brazil to include HIV1 antiretroviral therapy. After advent of HAART, morbidity and mortality rates decreased in this location. However, due to sequential therapy, antiretroviral failure and resistance are assumed to be high. Our objective has been to assess the immunological benefit to individuals under HAART with and without virologic suppression.

\section{Methods}

We studied 2,854 patients treated with antiretroviral therapy. Patients with 3 years continuous suppression of viremia (<50 HIV-RNA copies/ml, b-DNA, Siemens) were classified as group 1 and patients with 3 years continuous viremia (viral load $>10,000$ HIV-RNA copies $/ \mathrm{ml}$ ) were classified as group 2. The CD4+ and CD8+ T-cell data were retrospectively analyzed for the years 2005, 2006 and 2007.

\section{Summary of results}

$267(9.4 \%)$ patients on follow-up belonged to group 1 and $48(1.7 \%)$ patients were classified as group 2 . The average CD4+ T-cell counts for group 1 was 642, 660, 722 cells/mm3 in 2005, 2006 and 2007, respectively, and CD8+T average was $1085,987,1006$. The group 2 average CD4+T count was 427, 368, 315, and CD8+T mean: 1310 , 1247,1193 cells/mm3. There was a continuous increase in the CD4+ T-cell counts over time in group 1 (ANOVA, $\mathrm{p}<0.05$, $)$, as well as a decline in group $2(\mathrm{p}<0.01)$.

\section{Conclusion}

Although there have been descriptions of a continuous immunologic benefit among individuals under antiretroviral treatment in spite of virologic failure, it is clear that moderate to high levels of viremia will lead to a decrease in the average CD4 counts in a relatively short period of time in this population. Interestingly, both groups showed an equally high level of CD8+T cells in spite of the degree of viral suppression. Only $9.4 \%$ under treatment in the public system in this key location in Brazil present long-term viral suppression, which may be the characteristic of developing countries with widespread access to all FDA licensed antiretrovirals for all patients free of cost. 